\title{
Validation of satellite soil moisture in the absence of $i n$ situ soil moisture: the case of the Tropical Yankin Basin
}

\author{
Djigbo F. Badou ${ }^{1, *}$, Bernd Diekkrüger ${ }^{2}$, Carsten Montzka $^{3}$ \\ ${ }^{1}$ National Water Institute, University of Abomey-Calavi, 01 BP. 526 Cotonou, Benin \\ fdbadou@gmail.com \\ ${ }^{2}$ Department of Geography, University of Bonn, Meckenheimer Allee 166, 53115 Bonn, Germany \\ b.diekkrueger@uni-bonn.de \\ ${ }^{3}$ Forschungszentrum Jülich, Institute of Bio- and Geosciences: Agrosphere (IBG-3), Leo-Brandt- \\ Strasse, 52425 Jülich, Germany, c.montzka@fz-juelich.de
}

DOI: http://dx.doi.org/10.4314/sajg.v7i3.3

\begin{abstract}
Soil moisture is known to be important in hydrology, agronomy, flood and drought forecasting. Acquisition of in situ soil moisture data is time consuming, costly, and does not cover the scale required for basin analysis. The consideration of remotely-sensed soil moisture is therefore promising. However, considering the limitations of satellite data, there is a need to check their validity prior to their utilization for impact studies. This, in turn, poses a problem in the absence of in situ soil moisture. The present study suggests a methodology for testing the validity of remotelysensed soil moisture without in situ soil moisture. Hydrological models with a detailed soil moisture routine are calibrated and validated with measured stream flows. The most behavioural solutions of modelled soil moistures are averaged, and used as proxy measurements. This methodology was applied to the Yankin Basin (8,171 km²), a tributary of the Niger River Basin. The soil moistures of three hydrological models (UHP-HRU, SWAT and WaSiM) used as proxy were compared with the daily ESA-CCI soil moisture for a four year period (2005-2008). The coefficient of determination $\left(R^{2}\right)$, bias and visual inspection were used as quality criteria. A rather small bias ranging from $0.01 \mathrm{~cm}^{3} / \mathrm{cm}^{3}$ (SWAT \& UHP-HRU) to $-0.04 \mathrm{~cm}^{3} / \mathrm{cm}^{3}$ (WaSiM \&UHP-HRU) was determined as well as good $R^{2}$ varying between 0.71 (SWAT \& UHP-HRU) and 0.81 (WaSiM \& SWAT \& UHP-HRU). The ESA-CCI soil moisture was therefore judged as reliable for the study area. More important, this research shows that averaging soil moistures from different hydrological models provides valuable proxy measurements for testing the reliability of satellite soil moistures.
\end{abstract}

\section{Introduction}

Soil moisture is a key component of the environment to consider in hydrological modelling, agricultural production, flood and drought forecasting, and adaptation to climate change. Knowledge of soil moisture pattern and dynamics is thus an indispensable information. In situ observations and satellite products are the two common sources of soil moisture information (Mohanty et al., 2017). While ground-based soil moisture provides point scale information and is 
appropriate for studies at small scales, satellite soil moisture products, due to their large spatial coverage, offer countless of applications at regional, continental and global scales. Also, remotely sensed soil moisture is readily more available and accessible than in situ measurements which make them more attractive.

However, prior to their use for impact studies, the validity and accuracy of satellite data must be evaluated. Checking the quality of satellite soil moisture products can "easily" be envisaged when in situ soil moisture measurements are available. But even in that case, the comparison is not straightforward (Colliander, Jackson, et al., 2017; Montzka et al., 2017). Actually, one of the main criticisms on satellite soil moisture is their coarse resolution (25 to $50 \mathrm{~km})$ and their scale mismatch with in situ observations (Wanders et al., 2012). Piles et al. (2011) suggested a downscaling scheme to cope with this shortcoming of remotely sensed soil moisture. Several further methods have been developed to enhance the spatial resolution of coarse global soil moisture products (Verhoest et al., 2015; Im et al., 2016; Colliander, Fisher, et al., 2017; Jin et al., 2017; Montzka et al., 2018). Another possibility is the use of a distributed water balance model which allows the "upscaling" of in situ observations to match the scale of satellite products (e.g. Rötzer et al. 2014). An example of such possibility is given in the study of Wanders et al. (2012) who used the Soil-WaterAtmosphere-Plant model (SWAP, Kroes et al., 2008; Van Dam, 2000), a distributed unsaturated zone model to "upscale" in situ soil moisture to the scale of the SMOS (Soil Moisture and Ocean Salinity), ASMR-E (Advanced Microwave Scanning Radiometer) and ASCAT(Advanced Scatterometer) soil moisture products (The spatial resolution of SMOS, ASCAT and ASMR-E products was $35-50 \mathrm{~km}, 25 \mathrm{~km}$ and 36-54 km respectively (Wanders et al., 2012)

So far, all satellite soil moisture validation studies made use of in situ soil moisture or a combination of in situ and modelled soil moisture (Albergel et al., 2009; Albergel et al., 2011; Brocca et al., 2010; Draper et al., 2009; Lacava et al., 2012; Su et al., 2011; Wagner et al., 2007). As many regions in the world are poorly gauged or ungauged, the question which then arises is how to check the quality of remotely sensed soil moisture for data scarce regions.

To cope with this issue of in situ soil moisture availability, the ISMN (International Soil Moisture Network, http://ismn.geo.tuwien.ac.at/) has been set up to offer a web portal where standardised in situ soil moisture can be acquired (Dorigo et al., 2011). If the initiative comprises more than 500 stations worldwide, there are some regions with very poor or no soil moisture monitoring network especially in Africa and Latina America. In West Africa, for instance, according to Albergel et al. (2011) and Dorigo et al. (2011), the network of the AMMA (African Monsoon Multidisciplinary Analysis) project made up of 10 stations installed over three sites is the sole network.

Hence, an alternative have to be found for checking the quality of satellite soil moisture products for ungauged areas. This study suggests a framework to test the validity of remotely-sensed soil moisture without in situ soil moisture. 


\section{Materials and methods}

As displayed in Figure 1, the idea is the use of hydrological modelling to generate modelled soil moisture taken as reference data for the validation of satellite soil moisture. The principle is implemented in three steps. The first step is the calibration and validation of hydrological models with stream flow data which, generally, are available for most catchments. Such models should have a detailed soil moisture routine otherwise soil moisture cannot be extracted. A calibration and validation (and not only a calibration) ensures that the output of the models are reliable (Biondi et al., 2012). As hydrological models are per se uncertain (Pappenberger and Beven, 2006; Andreassian et al., 2009; Juston et al., 2012), we suggest that not only one single model but instead several models be used (Jiang et al., 2007; Foley, 2010; Badou, 2016). The second stage is the extraction of modelled soil moisture. Hydrological models deliver a range of solutions (and not a single one) corresponding to acceptable performance criteria, and acceptable representation of processes known as behavioural solutions (Beven and Binley, 1992; Abbaspour, 2008; Krauße, 2013). To guarantee that the modelled soil moisture to be taken as reference is the "best" choice, a safeguard would be to select the soil moisture of the most behavioural solutions. The last step is the actual comparison of remotely-sensed and modelled soil moisture. To deal with the uncertainty inherent to any hydrological model output that might bias the comparison, we further propose that extracted soil moisture from the candidate models be combined (use of average, percentiles or confidence levels). A multi-objective validation using a number of performance criteria such as the coefficient of determination $\left(\mathrm{R}^{2}\right)$, bias, root mean squared error (RMSE) and also visual inspection is necessary. It is worth noting that the suggested methodology is only recommended for the validation of satellite soil moisture over hydrological basins for which stream flow data are readily available (Dettinger and Diaz, 2000). It cannot be applied for geographical areas for which hydrological models cannot be calibrated and validated.

Calibrate and validate hydrological models having a detailed soil moisture routine using stream flow.

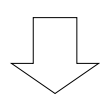

Extraction of simulated soil moisture (proxy) of the most behavioural solutions.

Comparison of simulated SM (proxy) with satellite soil moisture
Multi-model evaluation
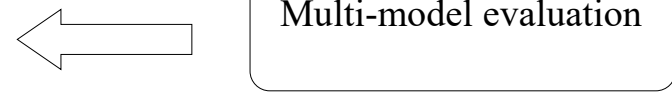

Multi-objective

validation

Multi-objective validation

Figure 1. Conceptual framework for the validation of satellite soil moisture without in situ soil moisture 


\section{Case study: Validation of the ESA-CCI soil moisture for the Yankin Basin}

\subsection{Overview of the test basin}

The Alibori $(427 \mathrm{~km})$ is the largest affluent of the Niger River basin in Benin Republic (Figure 2). It originates on the eastern side of the Atacora's chain at 410 m.a.s.1 in the commune of Péhunco and at mid-stream forms the Yankin Basin $\left(8,171 \mathrm{~km}^{2}\right)$.

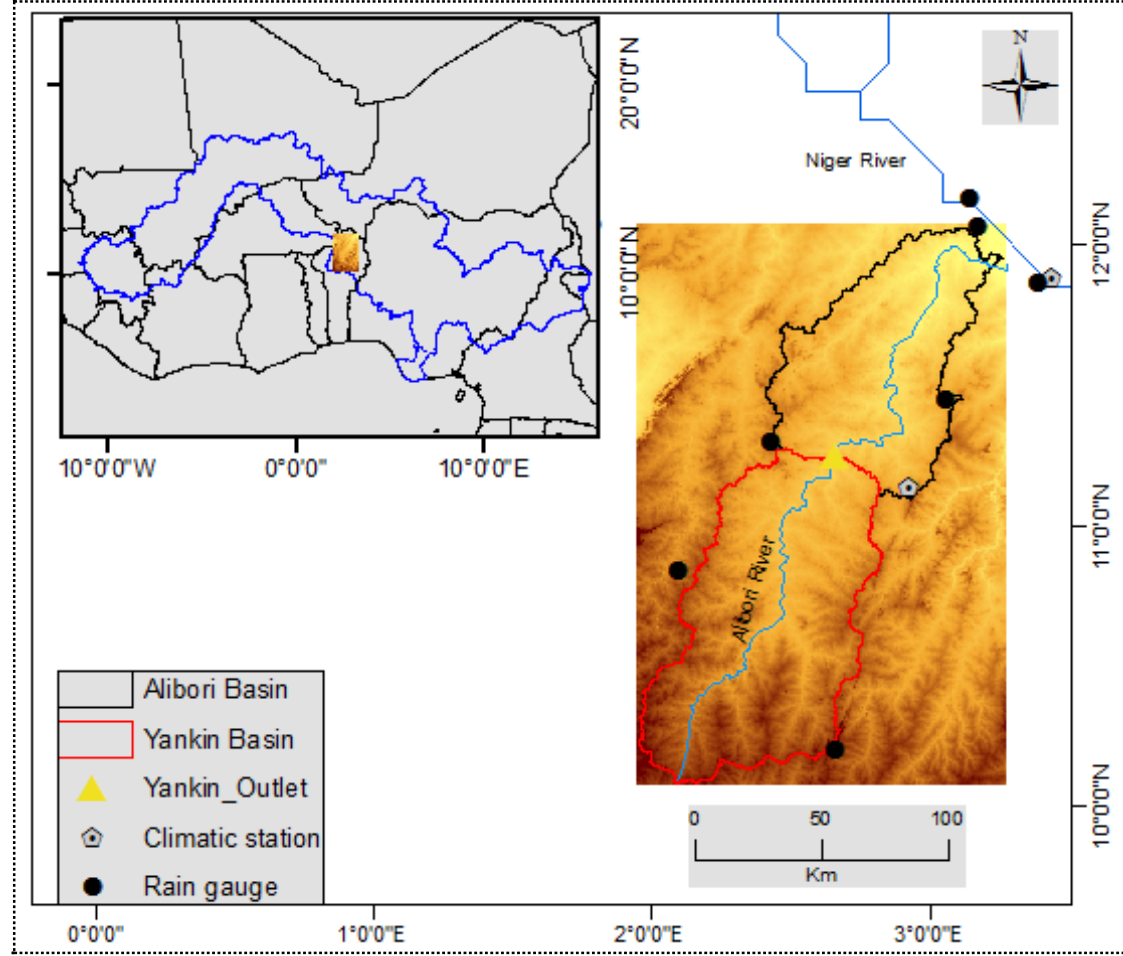

Figure 2. Overview of the Yankin basin in the Niger river basin located in Benin Republic

The vegetation is dominated by savannah, followed by farms and fallows then forest (CILSS, 2016). The climate is Sudano-sahelian with only one rainy season (April to October) and annual rainfall vary between $700 \mathrm{~mm}$ and $1250 \mathrm{~mm}$ while mean temperature is $28{ }^{\circ} \mathrm{C}$. Three major soil types are found in the Yankin Basin: Albic Plinthosol, Haplic Lixsol, and Ferric and Albic Acrisol.

\subsection{Hydrological models}

Three hydrological models having a detailed soil moisture routine, the Universal Hydrological Program - Hydrological Response Unit, UHP-HRU (Giertz et al., 2010), Soil Water Assessment Tool, SWAT (Arnold et al., 1998) and Water balance Simulation Model, WaSIM (Schulla, 1997; Schulla, 2012) were used. UHP-HRU is a conceptual, semi-distributed water balance model for assessing hydrological processes (surface runoff, interflow, baseflow, aquifer recharge, etc.). SWAT is also a conceptual, semi-distributed model developed for assessing the impacts of climate, land use and agricultural practices on water quality, water quantity and sediment. WaSiM is a physically-based and distributed model used for the simulation of water balance. A brief description 
of the models is given in Table 1. A more detailed description of each of these models can be found in Cornelissen, Diekkrüger and Giertz (2013).

The three models require the same input data (see Table 2) which are a digital elevation model, land use map related properties, soil map related properties, climate variables (rainfall, temperature, wind speed, humidity, and radiation). The Penman-Monteith method (Penman, 1956; Monteith, 1965) was used to compute potential evapotranspiration for the three models. Regardless of the model, stream flow is computed as the sum of surface runoff, interflow and baseflow.

Table 1. Comparison of the hydrological models used in this study with an emphasis on the soil

\begin{tabular}{|c|c|c|c|}
\hline \multicolumn{4}{|c|}{ moisture } \\
\hline & WaSiM & SWAT2009 & UHP-HRU \\
\hline Model type & $\begin{array}{l}\text { Physically-based and } \\
\text { distributed }\end{array}$ & $\begin{array}{l}\text { Conceptual and semi- } \\
\text { distributed }\end{array}$ & $\begin{array}{l}\text { Conceptual and semi- } \\
\text { distributed }\end{array}$ \\
\hline Spatial resolution & $\begin{array}{l}\text { Grid based spatial } \\
\text { discretisation }\end{array}$ & Fixed HRU & Variable HRU \\
\hline Soil module & $\begin{array}{l}\text { Richards' equation; soil is } \\
\text { divided into vertical layers. }\end{array}$ & $\begin{array}{l}\text { Tipping bucket; soil is } \\
\text { divided into soil layers }\end{array}$ & $\begin{array}{l}\text { Linear storage; soil is } \\
\text { divided into root and } \\
\text { unsaturated zones. }\end{array}$ \\
\hline $\begin{array}{l}\text { Simulated soil } \\
\text { moisture }\end{array}$ & For user-specified layers & $\begin{array}{l}\text { For each layer but only } \\
\text { provided as output as } \\
\text { integral of soil profile }\end{array}$ & $\begin{array}{l}\text { For the root and unsaturated } \\
\text { zones. }\end{array}$ \\
\hline Stream flow & $\begin{array}{l}\text { Sum of surface runoff, } \\
\text { interflow and baseflow }\end{array}$ & $\begin{array}{l}\text { Sum of surface runoff, } \\
\text { lateral flow and baseflow }\end{array}$ & $\begin{array}{l}\text { Sum of surface runoff, } \\
\text { interflow and baseflow }\end{array}$ \\
\hline
\end{tabular}

Using stream flow data, Badou (2016) calibrated and validated the three models for the 19841988 and 2005-2008 periods respectively. The calibration and validation were successful for three criteria, the Nash-Sutcliffe efficiency, NSE (Nash and Sutcliffe, 1970), Kling-Gupta efficiency, KGE (Gupta et al., 2009) and coefficient of determination, $\mathrm{R}^{2}$ and were unsatisfactory to very good for the percent bias criterion, PBIAS (Gupta et al., 1999). 
Table 2. Summary of the data used for the study, modified after Badou (2016)

\begin{tabular}{|c|c|c|c|}
\hline \multirow[t]{2}{*}{ Data } & $\begin{array}{l}\text { Resolution } \\
\text { (scale) }\end{array}$ & \multirow[t]{2}{*}{ Relevance } & \multirow[t]{2}{*}{ Sources } \\
\hline & Time period & & \\
\hline \multirow{2}{*}{ Climatic } & 12 stations & & \multirow{2}{*}{ DMN Benin } \\
\hline & 1984-2008 & & \\
\hline Topographic & $30 \times 30 \mathrm{~m}$ & $\begin{array}{l}\text { Delineation of subbasins and HRU, topographic } \\
\text { parameters }\end{array}$ & ASTER GDEM \\
\hline Land use & $\begin{array}{l}1: 50,000 \\
1979\end{array}$ & $\begin{array}{l}\text { HRU delineation, root depth, leaf area index, albedo, } \\
\text { interception factor, etc. }\end{array}$ & CENATEL \\
\hline Soil & $\begin{array}{l}1: 200,000 \\
1978\end{array}$ & Texture, bulk density, hydraulic conductivity, etc. & ORSTOM \\
\hline Streamflow & $\begin{array}{l}01 \text { station } \\
1984-2008\end{array}$ & To generate simulated soil moisture used as proxy & DGEau \\
\hline \multirow{3}{*}{ Soil moisture } & $0.25^{\circ} \times 0.25^{\circ}$ & & \multirow{3}{*}{ ESA-CCI } \\
\hline & Topmost $2 \mathrm{~cm}$ & & \\
\hline & $2005-2008$ & & \\
\hline
\end{tabular}

ASTER GDEM stands for Advanced Spaceborne Thermal Emission and Reflection Radiometer Global Digital Elevation Model, CENATEL for Centre National de Télédétection et de Suivi Ecologique du Bénin, DMN for Direction Météorologique Nationale, ESA CCI for European Space Agency Climate Change Initiative and ORSTOM for Office pour la Recherche Scientifique et Technique d'Outre Mer (Office for Overseas Scientific and Technical Research; now IRD).

The soil moisture data of the best solution of each of the three models were extracted for comparison with the ESA-CCI (European Space Agency Climate Change Initiative http://www.esacci.org/) soil moisture for the validation period. As shown in Table 2, the remotely-sensed product has a spatial resolution of $0.25^{\circ} \times 0.25^{\circ}$ and is given for the topmost $2 \mathrm{~cm}$ at the daily time step. More details on the ESA-CCI soil moisture can be found in Liu et al. (2012). While for WaSiM the soil moisture of the uppermost $2 \mathrm{~cm}$ layer was extracted, the soil moisture of the SWAT and UHPHRU models were rescaled using straightforward proportions. To test the benefit of combining soil moistures from two or more models instead of using that of one single model (see Section 2), modelled soil moistures were averaged for all possible combinations (SWAT and UHP-HRU/ SWAT and WaSiM/ UHP-HRU and WaSiM/ SWAT, UHP-HRU and WaSiM). We, then, computed and analysed the difference between modelled soil moistures (both for individual models and their combinations) and satellite soil moisture.

\subsection{Results}

Modelled and remotely-sensed soil moistures were compared using graphical technique and quantitative metrics.

\subsubsection{Graphical technique}

Figure 3 and Figure 4 display the graphs of the comparison of modelled and ESA-CCI soil moisture for the study area. 
When modelled soil moisture from individual model is used, UHP-HRU seems the best case of agreement between modelled and satellite soil moisture especially for the years 2007 and 2008 . Satellite data underestimate SWAT soil moisture and lead to high discrepancies (nearly 0.2 $\mathrm{cm}^{3} / \mathrm{cm}^{3}$ ) for the years 2005, 2007 and 2008 on the one hand and overestimate WaSiM values with a difference of $-0.15 \mathrm{~cm}^{3} / \mathrm{cm}^{3}$ on the other hand.

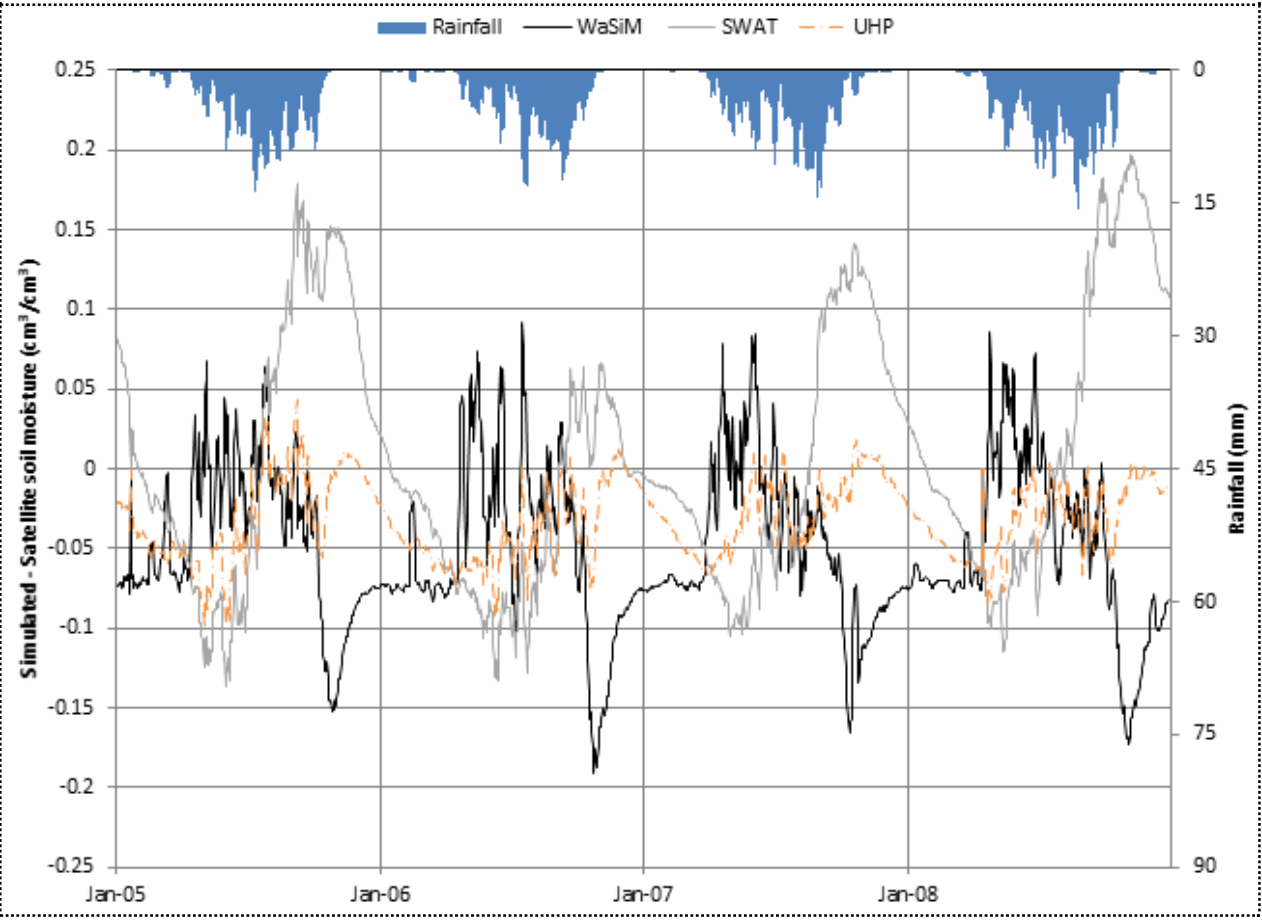

Figure 3. Difference between catchment averaged modelled and satellite soil moistures for the WaSiM, SWAT and UHP-HRU models.

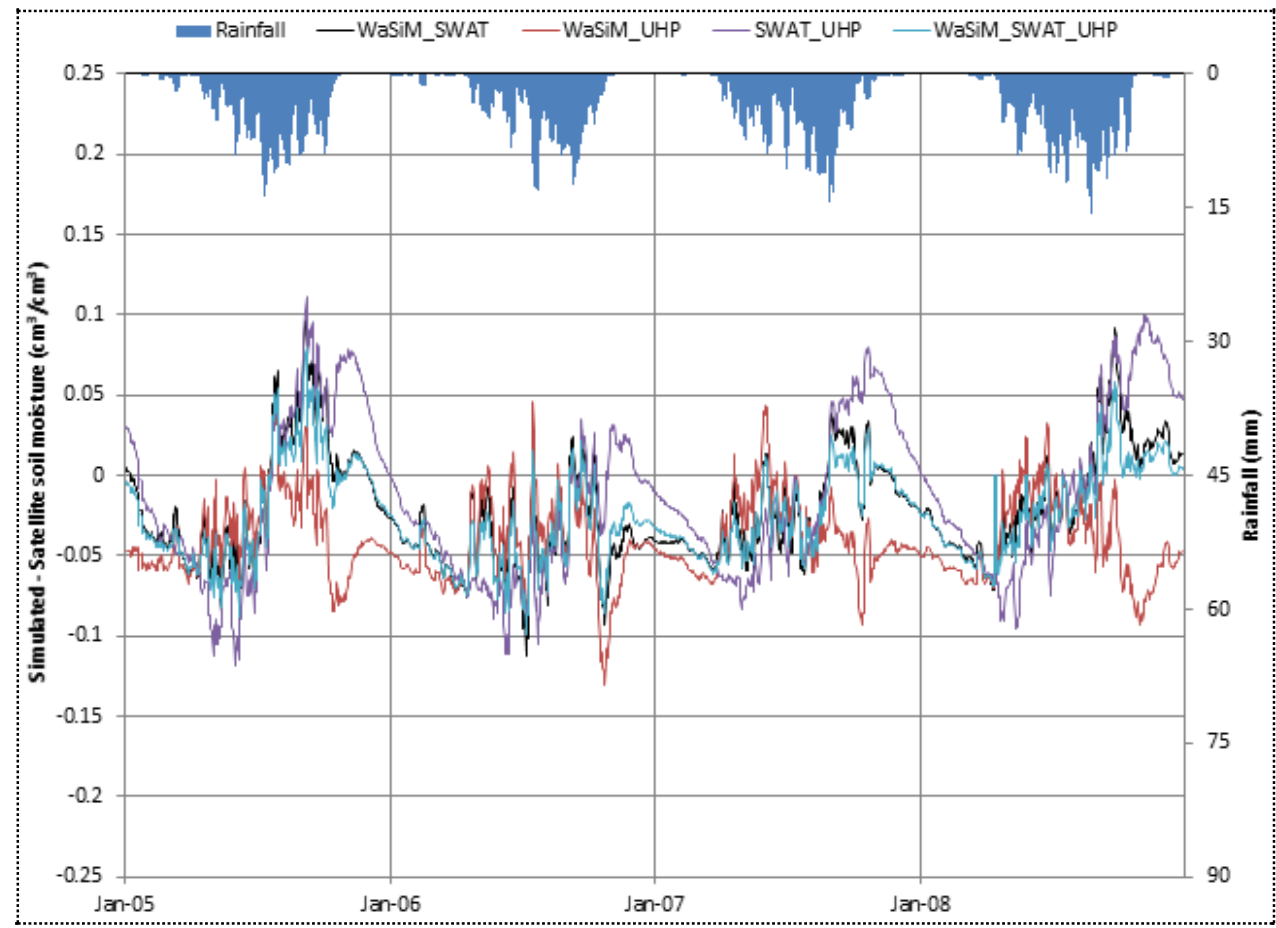

Figure 4. Difference between catchment averaged modelled and satellite soil moistures for the combinations of the WaSiM, SWAT and UHP-HRU models. 
In comparison with Figure 3, Figure 4 clearly shows that with the combination of models soil moisture, results are improved. The best outcome is obtained when the soil moisture of the three models are averaged. The graph "WaSiM_SWAT_UHP" shows discrepancies barely greater than $0.05 \mathrm{~cm}^{3} / \mathrm{cm}^{3}$ (in absolute values) for 2007 and 2008, and lesser than $0.1 \mathrm{~cm}^{3} / \mathrm{cm}^{3}$ (in absolute values) for 2005-2006. Likewise, averaging WaSiM and SWAT outputs lead to small discrepancies between modelled and satellite soil moisture for 2007, and quite similar results for 2008 and 20052006 but to a lesser extent than in the case of the combination of the three models. With the combination of WaSiM and UHP-HRU, negative biases $\left(-0.08\right.$ to $\left.-0.13 \mathrm{~cm}^{3} / \mathrm{cm}^{3}\right)$ are found for each of the four year of the comparison. The poorest fit was obtained for the combination of SWAT and UHP-HRU with absolute biases of more or less $0.1 \mathrm{~cm}^{3} / \mathrm{cm}^{3}$ except for 2007 . However, this poor fit is, by far, better than the fit obtained when SWAT and WaSiM soil moisture are taken individually.

\subsubsection{Quantitative measures}

Table 3 and Table 4 showcase the quantitative metrics of the comparison between modelled and satellite soil moisture when single model outputs are considered and when models outputs are combined respectively. An analysis of these tables reveals that with the combination of models soil moisture improve the results especially with respect to the $\mathrm{R}^{2}$ criterion.

Considering the bias metric, the lowest absolute value $\left(0.01 \mathrm{~cm}^{3} / \mathrm{cm}^{3}\right)$ is determined for SWAT while the highest value $\left(-0.048 \mathrm{~cm}^{3} / \mathrm{cm}^{3}\right)$ corresponds to the comparison with WaSiM soil moisture. Combined models and satellite soil moisture yield smaller biases with a maximum bias of $0.039 \mathrm{~cm}^{3} / \mathrm{cm}^{3}$ against $-0.048 \mathrm{~cm}^{3} / \mathrm{cm}^{3}$ for the WaSiM model taken individually. Concerning individual models, the lowest and highest biases are obtained for SWAT and WASIM soil moistures respectively. Averaging modelled soil moistures, the lowest bias is given for the combination SWAT and UHP-HRU while the highest bias corresponds to the combination of UHPHRU and WaSiM. Thus, the combination of modelled soil moistures seems to be linear with respect to the bias criterion.

Table 3. Comparison of modelled and remotely-sensed soil moisture for the WaSiM, SWAT and UHP-HRU models.

\begin{tabular}{lccc}
\hline Model & UHP-HRU & SWAT & WaSiM \\
\hline $\begin{array}{l}\text { Mean modelled SM } \\
\left(\mathrm{cm}^{3} / \mathrm{cm}^{3}\right)\end{array}$ & 34.4 & 45.77 & 29.52 \\
\hline $\begin{array}{l}\text { Mean remotely-sensed SM } \\
\left(\mathrm{cm}^{3} / \mathrm{cm}^{3}\right)\end{array}$ & 42.85 & 42.85 & 42.85 \\
\hline $\begin{array}{l}\text { Mean bias } \\
\left(\mathrm{cm}^{3} / \mathrm{cm}^{3}\right)\end{array}$ & -0.03 & 0.01 & -0.048 \\
\hline $\mathrm{R}^{2}$ & 0.83 & 0.57 & 0.54 \\
\hline
\end{tabular}


Table 4. Comparison of modelled and remotely-sensed soil moisture for the combinations of the WaSiM, SWAT and UHP-HRU models.

\begin{tabular}{lcccc}
\hline Model & WaSiM_SWAT & WaSiM_UHP & SWAT_UHP & WaSiM_SWAT_UHP \\
\hline $\begin{array}{l}\text { Mean modelled } \\
\text { SM }\left(\mathrm{cm}^{3} / \mathrm{cm}^{3}\right)\end{array}$ & 45.743 & 38.861 & 48.939 & 44.514 \\
\hline $\begin{array}{l}\text { Mean remotely- } \\
\begin{array}{l}\text { sensed SM } \\
\left(\mathrm{cm}^{3} / \mathrm{cm}^{3}\right)\end{array}\end{array}$ & 42.850 & 42.850 & 42.850 & 42.850 \\
\hline $\begin{array}{l}\text { Mean bias } \\
\left(\mathrm{cm}^{3} / \mathrm{cm}^{3}\right)\end{array}$ & -0.019 & -0.039 & -0.010 & -0.023 \\
\hline $\mathrm{R}^{2}$ & 0.77 & 0.77 & 0.71 & 0.81 \\
\hline
\end{tabular}

With respect to the coefficient of determination, very good score $(0.83)$ is obtained for the comparison of remotely-sensed soil moisture with soil moisture modelled using UHP-HRU while the comparison with the two other models yield only satisfactory result (0.54 and 0.57$)$. A minimum $\mathrm{R}^{2}$ value of 0.71 is obtained for the comparison with averaged models soil moisture showing the benefit of averaging models soil moisture. Considering models individually, the highest and lowest $\mathrm{R}^{2}$ values are obtained for the comparison with UHP-HRU and WASIM soil moistures respectively. Averaging modelled soil moistures, the highest $\mathrm{R}^{2}$ is given for the comparison with WaSiM and SWAT soil moistures while the lowest corresponds to the comparison with SWAT and UHP-HRU. Hence, the combination of models seems to be non-linear with respect to the $\mathrm{R}^{2}$ measure of goodness of fit.

\subsection{Discussion}

When the ESA-CCI soil moisture product is compared with averaged modelled soil moistures the discrepancies are smaller and the correlations higher than when the comparison is done with soil moisture from individual models alone. When modelled soil moisture from either SWAT or WaSiM model were compared to satellite soil moisture, the ESA-CCI soil moisture was evaluated as poor (see Figure 3). Conversely, when soil moisture from the models are averaged and taken as a reference a better score is obtained and the ESA-CCI product is acceptable (see Figure 4 and Table 4). The combination of models soil moisture is more reliable because the soil moisture of the models taken individually are poorly correlated among themselves (see Figure 3) while the combined models soil moisture yield a good timing among themselves especially during the rainy season (see Figure 4). Differences between modelled soil moistures might emanate from the differences between soil moisture computation procedures of the individual models. UHP-HRU only simulates the water available for plants within the root zone, SWAT simulates the moisture of each user-specified layer but only provides it for the entire soil depth, and WaSiM simulates the soil moisture of user-specified layers (Table 1). The mismatch between the thicknesses of the ESA-CCI soil moisture $(2 \mathrm{~cm})$ and that of the modelled soil moistures which necessitated scaling down SWAT and UHP-HRU soil moistures to $2 \mathrm{~cm}$ (Section 3.2) might have also contributed to these differences. Hence, the largest discrepancies were obtained with the SWAT model whose soil moisture is provided for the entire soil depth (Figure 3). Combining hydrological models outputs 
has been reported to improve the representativeness of the processes (Viney et al., 2009). The fact that the correlation is higher when the soil moistures of the three models are averaged suggests that individual models weaknesses are compensated while their strengths are amplified. However, these are not a linear relationships.

The findings presented in this case study are partly consistent with previous studies on the validation of satellite soil moisture datasets. Albergel et al. (2011) analysed the reliability of the soil moisture products from the ECMWF (European Centre for Medium Range Weather Forecasts), ASCAT and SMOS for 200 stations located in the US, Europe, Australia and Africa including 6 stations from the AMMA stations located nearby the Yankin Basin. They found an $\mathrm{R}^{2}$ of $0.42,0.45$ and 0.55 and a bias of $0.079,-0.074$ and -0.179 for the SMOS, ECMWF and ASCAT respectively. Brocca et al. (2012) compared ASCAT and modelled soil moisture for the surface layer and the root zone in the Niccone basin in Central Italy. They reported a high correlation of 0.78 and 0.98 for the surface and root zone respectively. Leroux et al. (2013) assessed the quality of the SMOS soil moisture for the year 2010 by comparing it with ground data and three other soil moisture products ASCAT, VUA (AMSR-E soil moisture product from the Vrije University of Amsterdam) and ECMWF for four watersheds of the US. They found that the SMOS correlate reasonably well with in situ measurements and that the ECMWF and VUA have good correlations but high biases. The quality of the SMOS soil moisture of the year 2010 was also investigated by Sánchez et al. (2012) in comparison with observations from REMEDHUS network in Spain. A good fit was found between the two soil moisture products with an $\mathrm{R}^{2}$ of 0.73 and a bias of $0.053 \mathrm{~m}^{3} / \mathrm{m}^{3}$. Similar results were found for the ESA CCI soil moisture product in China (An et al., 2016) and East Africa (McNally et al., 2016).

\section{Conclusion}

The validation of satellite soil moisture products is the focus of increasing studies. This research suggested a methodology applicable to hydrological basins where in situ soil moisture measurements are not available. The basic idea is to use water balance models to generate proxy measurements. Some safeguards are suggested to ensure that modelled soil moistures are reliable and less uncertain: a multi-model approach i.e. the use of several hydrological models, a multiobjective validation of these models, the extraction of the most behavioural solutions, and the combination of the extracted soil moistures (use of average, percentiles or confidence levels). The methodology was successfully tested for the ESA-CCI soil moisture product over the tropical Yankin Basin in Benin for which three hydrological models with detailed soil moisture modules (SWAT, UHP-HRU and WaSiM) were used. ESA-CCI and modelled soil moistures were compared for a period of four years, 2005-2008. It was found that:

(i) using single model soil moistures as proxy measurements, the ESA-CCI soil moistures show small discrepancies $\left(-0.1\right.$ to $\left.0.05 \mathrm{~cm}^{3} / \mathrm{cm}^{3}\right)$ only for the UHP-HRU derived soil moistures, 
(ii) using averaged modelled soil moistures as proxy measurements, maximum and minimum discrepancies values are reduced by nearly $0.1 \mathrm{~cm}^{3} / \mathrm{cm}^{3}$ in comparison to the case when models are considered individually; and

(iii) the smallest discrepancies $\left(0.05 \mathrm{~cm}^{3} / \mathrm{cm}^{3}\right)$ and best performance $\left(\mathrm{R}^{2}\right.$ of 0.81$)$ are obtained when the soil moistures from the three models are averaged and used as proxy measurements.

(iv) the combination of modelled soil moistures seems to be linear with respect to the bias accuracy metric but non-linear for the coefficient of determination $\left(\mathrm{R}^{2}\right)$.

Our results suggest that averaging soil moistures from different hydrological models provides valuable proxy measurements for testing the reliability of satellite soil moistures.

To further evaluate the robustness of the suggested methodology, research on different satellite soil moisture products and different hydrological models over areas of different climatic conditions is needed.

\section{Acknowledgement}

This study was conducted at the Graduate Research Programme on Climate Change and Water Resources of the University of Abomey-Calavi in the framework of the WASCAL Initiative and funded by German Ministry of Education and Research (BMBF).

\section{Reference}

Abbaspour, K. C. (2008) 'SWAT-CUP2: SWAT Calibration and Uncertainty Programs - A User Manual. Department of Systems Analysis, Integrated Assessment and Modelling (SIAM), Eawag, Swiss Federal Institute of Aquatic Science and Technology, Duebendorf, Switzerland', p. 95.

Albergel, C., de Rosnay, P., Gruhier, C., Muñoz-sabater, J., Hasenauer, S., Isaksen, L., Kerr, Y. and Wagner, W. (2011) Evaluation of remotely sensed and modelled soil moisture products using global ground-based in situ observations. Berkshire, England. Available at: http://www.ecmwf.int/publications/.

Albergel, C., Rudiger, C., Carrer, D., Calvet, J.-C., Fritz, N., Naeimi, V., Bartalis, Z. and Hasenauer, S. (2009) 'An evaluation of ASCAT surface soil moisture products with in-situ observations in Southwestern France', Hydrology and Earth System Sciences, 13, pp. 115-124. Available at: www.hydrol-earth-syst-sci.net/13/115/2009/.

An, R., Zhang, L., Wang, Z., Quaye-Ballard, J. A., You, J., Shen, X., Gao, W., Huang, L., Zhao, Y. and Ke, Z. (2016) 'Validation of the ESA CCI soil moisture product in China', International Journal of Applied Earth Observation and Geoinformation, 48, pp. 28-36. doi: https://doi.org/10.1016/j.jag.2015.09.009.

Andreassian, V., Perrin, C., Berthet, L., Moine, N. Le, Lerat, J., Loumagne, C., Oudin, L., Mathevet, T., Ramos, M. H., Val, A., Andreassian, V., Perrin, C., Berthet, L., Moine, N. Le and Lerat, J. (2009) 'Crash tests for a standardized evaluation of hydrological models’, Hydrol. Earth Syst. Sci., 13, pp. 1757-1764.

Arnold JG, Srinivasan R, Muttiah RS, W. J. (1998) 'Large area hydrologic modeling and assessment-Part 1: Model development', Journal of the American Water Resources Association, 34, pp. 73-89.

Badou, D. F. (2016) Multi-model evaluation of blue and green water availability under climate change in four non-Sahelian basins of the Niger River basin. Published PhD Thesis, pp.1-155. University of 
Abomey-Calavi, Benin. Available at: http://www.wascal-uac.org/new/thesis/DjigboFélicienBADOU.pdf. Beven, K. J. and Binley, A. (1992) 'The future of distributed models: Model calibration and uncertainty prediction.', Hydrological Processes, 6(3), pp. 279 - 298. doi: 10.1002/hyp.3360060305.

Biondi, D., Freni, G., Iacobellis, V., Mascaro, G. and Montanari, A. (2012) 'Validation of hydrological models: Conceptual basis, methodological approaches and a proposal for a code of practice', Physics and Chemistry of the Earth, 42-44, pp. 70-76. doi: 10.1016/j.pce.2011.07037.

Brocca, L., Melone, F., Moramarco, T., Wagner, W. and Hasenauer, S. (2010) 'ASCAT soil wetness index validation through in situ and modeled soil moisture data in central Italy', Remote Sensing of Environment, 114, pp. 2745-2755. doi: 10.1016/j.rse.2010.06.009.

Brocca, L., Moramarco, T., Melone, F., Wagner, W., Hasenauer, S. and Hahn, S. (2012) 'Assimilation of Surface- and Root-Zone ASCAT Soil Moisture Products Into Rainfall - Runoff Modeling', IEEE Transactions on Geoscience and Remote Sensing, 50, pp. 2542-2555. doi: 10.1109/TGRS.2011.2177468.

CILSS (2016) Landscapes of West Africa - A Window On A Changing World. U.S. Geological Survey EROS, 47914 252nd St, Garretson, SD 57030, United States. Available at: https://eros.usgs.gov/westafrica/.

Colliander, A., Fisher, J. B., Halverson, G., Merlin, O., Misra, S., Bindlish, R., Jackson, T. J. and Yueh, S. (2017) 'Spatial Downscaling of SMAP Soil Moisture Using MODIS Land Surface Temperature and NDVI During SMAPVEX15', IEEE Geoscience and Rempte Sensing Letters, 14(11), pp. 2107-2111.

Colliander, A., Jackson, T. ., Bindlish, R., Chana, S., N., D., S.B.Kim, Cosh, M. ., Dunbar, B. ., Dang, L., L.Pashaian, Asanum, J., Aida, K., Berg, A., Rowlandson, T., Bosch, D., Caldwell, T., Caylor, K., D.Goodrich, ... and Yueh, S. (2017) 'Validation of SMAP surface soil moisture products with core validation sites', Remote Sensing of Environment, 191, pp. 215-231. doi: https://doi.org/10.1016/j.rse.2017.01.021.

Cornelissen, T., Diekkrüger, B. and Giertz, S. (2013) 'A comparison of hydrological models for assessing the impact of land use and climate change on discharge in a tropical catchment', Journal of Hydrology, 498, pp. 221-236. doi: 10.1016/j.jhydrol.2013.06.016.

Van Dam, J. C. (2000) Field scale water flow and solute transport. SWAP model concepts, parameter estimation and case studies. Published PhD thesis, pp.1-179. Wageningen University, Netherlands. Available at: http://library.wur.nl/WebQuery/wurpubs/fulltext/121243.

Dettinger, M. D. and Diaz, H. F. (2000) 'Global Characteristics of Stream Flow Seasonality and Variability', Journal of Hydrometeorology, 1, pp. 289-310. doi: 0.1175/1525-7541(2000)001.

Dorigo, W. A., Wagner, W., Hohensinn, R., Hahn, S., Paulik, C., Xaver, A., Gruber, A., Drusch, M., Mecklenburg, S., van Oevelen, P., Robock, A. and Jackson, T. (2011) 'The International Soil Moisture Network: a data hosting facility for global in situ soil moisture measurements', Hydrology and Earth System Sciences, 15, pp. 1675-1698. doi: 10.5194/hess-15-1675-2011.

Draper, C. S., Walker, J. P., Steinle, P. J., de Jeu, R. A. M. and Holmes, T. R. H. (2009) 'An evaluation of AMSR- E derived soil moisture over Australia’, Remote Sensing of Environment, 113, pp. 703-710. doi: 10.1016/j.rse.2008.11.011.

Foley, A. M. (2010) 'Uncertainty in regional climate modelling: A review', Progress in Physical Geography, 34(5), pp. 647-670. doi: 10.1177/0309133310375654.

Giertz, S., Hiepe, C., Steup, G., Sintondji, L., Diekkrüger, B. (2010) Hydrological processes and soil degradation in Benin in: Speth, P., Christoph, M., Diekkrüger, B. (Eds.), Impacts of Global Change on the Hydrological Cycle in West and Northwest Africa. Springer. Berlin.

Gupta, H. V., Kling, H., Yilmaz, K. K. and Martinez, G. F. (2009) 'Decomposition of the mean squared error and NSE performance criteria: Implications for improving hydrological modelling', Journal of Hydrology, 377, pp. 80-91. doi: 10.1016/j.jhydrol.2009.08.003.

Gupta, H. V., Sorooshian, S. and Yapo, P. O. (1999) 'Status of automatic calibration for hydrologic models: Comparison with multilevel expert calibration.', Journal of Hydrologic Engineering, 4(2), pp. 135-143. doi: http://dx.doi.org/10.1061/(ASCE)1084-0699(1999)4:2(135). 
Im, J., Park, S., Rhee, J., Baik, J. and Choi, M. (2016) 'Downscaling of AMSR-E soil moisture with MODIS products using machine learning approaches', Environmental Earth Sciences, 75(15). doi: 10.1007/s12665-016-5917-6.

Jiang, T., David, Y., Xu, C., Chen, X., Singh, V. P. and Chen, X. (2007) 'Comparison of hydrological impacts of climate change simulated by six hydrological models in the', Journal of Hydrology, 336, pp. 316-333. doi: 10.1016/j.jhydrol.2007.01.010.

Jin, Y., Ge, Y., Wang, J., Chen, Y., Heuvelink, G. B. M. and Atkinson, P. M. (2017) 'Downscaling AMSR-2 Soil Moisture Data With Geographically Weighted Area-to-Area Regression Kriging', IEEE Transactions on Geoscience and Remote Sensing, 56(4), pp. 2362-2376. doi: 10.1109/TGRS.2017.2778420.

Juston, J. M., Kauffeldt, A., Montano, B. Q., Seibert, J., Beven, K. J. and Westerberg, I. K. (2012) 'Smiling in the rain: Seven reasons to be positive about uncertainty in hydrological modelling. Invited Commentary', Hydrological Processes, 27(7), pp. 1117-1122. doi: 10.1002/hyp.9625.

Krauße, T. (2013) Robust parameter estimation - chances for hydrologic modelling in uncertain conditions. Published PhD thesis,pp. 1-131. Technische Universität Dresden, Germany. Available at: https://www.researchgate.net/publication/259482759_Robust_parameter_estimation__chances_for_hydrologic_modelling_in_uncertain_conditions.

Kroes, J. G., van Dam, J. C., Groenendijk, P., Hendriks, R. F. A. and Jacobs, C. M. J. (2008) 'SWAP version 3.2 -Theory description and user manual'. Alterra and Wageningen, pp. 1-284. Available at: https://library.wur.nl/WebQuery/wurpubs/fulltext/176385.

Lacava, T., Matgen, P., Brocca, L., Bittelli, M., Pergola, N., Moramarco, T. and Tramutoli, V. (2012) 'A First Assessment of the SMOS Soil Moisture Product With In Situ and Modeled Data in Italy and Luxembourg', IEEE Transactions on Geoscience and Remote Sensing, 50, pp. 1612-1622. doi: 10.1109/TGRS.2012.2186819.

Leroux, D., Kerr, Y. H., Albitar, A., Bindlish, R., Jackson, T. J., Berthelot, B. and Portet, G. (2013) 'Comparison between SMOS, VUA, ASCAT, and ECMWF soil moisture products over four watersheds in U.S.', IEEE Transactions on Geoscience and Remote Sensing, 52(3), pp. 1901-1906. doi: 10.1109/TGRS.2013.2252468.

Liu, Y. Y., Dorigo, W. A., Parinussa, R. M., de Jeu, R. A. M., Wagner, W., McCabe, M. F., Evans, J. P. and van Dijk, A. I. J. M. (2012) 'Trend-preserving blending of passive and active microwave soil moisture retrievals', Remote Sensing of Environment, 123, pp. 280-297. doi: 10.1016/j.rse.2012.03.014.

McNally, A., Shukla, S., Arsenault, K. R., Wang, S., Peters-Lidard, C. D. and Verdin, J. P. (2016) 'Evaluating ESA CCI soil moisture in East Africa', International Journal of Applied Earth Observation and Geoinformation, 48, pp. 96-109. doi: 10.1016/j.jag.2016.01.001.

Mohanty, B. P., Cosh, M. H., Lakshmi, V. and Montzka, C. (2017) 'Soil Moisture Remote Sensing: State-ofthe-Science', Vadose Zone Journal, 16(1), pp. 1-9. doi: 10.2136/vzj2016.10.0105.

Monteith, J. L. (1965) 'Evaporation and environment', in The State and Movement of Water in Living Organisms. XIXth Symposium of the Society for Experimental Biology,. Swansea: Cambridge University Press, pp. 205-234.

Montzka, C., Bogena, H. R., Zreda, M., Monerris, A., Morrison, R., Muddu, S. and Vereecken, H. (2017) 'Validation of Spaceborne and Modelled Surface Soil Moisture Products with Cosmic-Ray Neutron Probes', Remote sensing, 9(2:103), pp. 1-30. doi: 10.3390/rs9020103.

Montzka, C., Rötzer, K., Bogena, H. R., Sanchez, Ni. and Vereecken, H. (2018) 'A New Soil Moisture Downscaling Approach for SMAP, SMOS, and ASCAT by Predicting Sub-Grid Variability', Remote sensing, 10(3), p. 427. doi: 10.3390/rs10030427.

Nash, J. E. and Sutcliffe, J. V. (1970) 'River flow forecasting through conceptual models - Part I - A discussion of principles.', Journal of Hydrology, 10(3), pp. 282-290. doi: doi.org/10.1016/00221694(70)90255-6.

Pappenberger, F. and Beven, K. J. (2006) 'Ignorance is bliss: Or seven reasons not to use uncertainty 
analysis', Water Resources Research, 42(5), p. W05302. doi: 10.1029/2005WR004820.

Penman, H. L. (1956) 'Evaporation: An introductory survey', Netherlands Journal of Agricultural Science, 4, pp. 7-29.

Piles, M., Camps, A., Vall-llossera, M., Corbella, I., Panciera, R., Rüdiger, C., Kerr, Y. H. and Walker, J. (2011) 'Downscaling SMOS-Derived Soil Moisture Using MODIS Visible/Infrared Data', IEEE Transactions on Geoscience and Remote Sensing, 49, pp. 3156-3166. doi: 10.1109/TGRS.2011.2120615.

Rötzer, K., Montzka, C., Bogena, H., Wagner, W., Kerr, Y. H., Kidd, R. and Vereecken, H. (2014) 'Catchment scale validation of SMOS and ASCAT soil moisture products using hydrological modeling and temporal stability analysis', Journal of Hydrology, 519, pp. 934-946. doi: 10.1016/j.jhydrol.2014.07.065.

Sánchez, N., Martínez-fernández, J., Scaini, A. and Pérez-gutiérrez, C. (2012) 'Validation of the SMOS L2 Soil Moisture Data in the REMEDHUS Network (Spain)', IEEE Transactions on Geoscience and Remote Sensing, 50, pp. 1602-1611. doi: 10.1109/TGRS.2012.2186971.

Schulla, J. (1997) Hydrologische Modellierung von Flussgebieten zur Abschätzung der Folgen von Klimaänderungen. Published PhD thesis, pp.1-189. Technische Universität Dresden, Germany. Available at: http://www.wasim.ch/downloads/doku/wasim/schulla_1997.pdf.

Schulla J. (2012) Model Description WaSiM. Zürich, Switzerland. Available at: http://www.wasim.ch/downloads/doku/wasim/wasim_2012_en.pdf.

Su, Z., Wen, J., Dente, L., Van der Velde, R., Wang, L., Ma, Y., Yang, K. and Hu, Z. (2011) 'The Tibetan Plateau observatory of plateau scale soil moisture and soil temperature (Tibet-Obs) for quantifying uncertainties in coarse resolution satellite and model products', Hydrology and Earth System Sciences, 15, pp. 2303-2316. doi: 10.5194/hess-15-2303-2011.

Verhoest, N. E. C., van den Berg, M. J., Martens, B., Lievens, H., Wood, E. F., Pan, M., Kerr, Y. H., Bitar, A. Al, Tomer, S. K., Drusch, M., Vernieuwe, H., De Baets, B., Walker, J. P., Dumedah, G. and Pauwels, V. R. N. (2015) 'Copula-Based Downscaling of Coarse-Scale Soil Moisture Observations With Implicit Bias Correction', IEEE Geoscience and Remote Sensing, 53(6), pp. 3507-3521. doi: 10.1109/TGRS.2014.2378913.

Viney, N.R., Bormann, H., Breuer, L., Bronstert, A., Croke, B.F.W., Frede, H., Gräff, T., Hubrechts, L., Huisman, J.A., Jakeman, A.J., Kite, G.W., Lanini, J. Leavesley, G., Lettenmaier, D.P., Lindström, G. Seibert, J., Sivapalan, M. and Willems, P. (2009) 'Assessing the impact of land use change on hydrology by ensemble modelling (LUCHEM) II: Ensemble combinations and predictions', Advances in Water Resources, 32(2), pp. 147-158.

Wagner, W., Naeimi, V., Scipal, K., de Jeu, R. and Martínez-Fernández, J. (2007) 'Soil moisture from operational meteorological satellites', Hydrogeology Journal, 15, pp. 121-131. doi: 10.1007/s10040-0060104-6.

Wanders, N., Karssenberg, D., Bierkens, M., Parinussa, R., de Jeu, R., Dam, J. Van and de Jong, S. (2012) 'Observation uncertainty of satellite soil moisture products determined with physically-based modeling', Remote Sensing of Environment, 127, pp. 341-356. doi: 10.1016/j.rse.2012.09.004. 